\title{
Multilevel genetic analyses of two European supercolonies of the Argentine ant, Linepithema humile
}

\author{
J. JAQUIÉRY, V. VOGEL and L. KELLER \\ Department of Ecology and Evolution, Biology Building, University of Lausanne, CH-1015 Lausanne, Switzerland
}

\begin{abstract}
Some ants have an extraordinary unicolonial social organization, whereby individuals mix freely among physically separated nests. Recently, it was shown that the European population of Linepithema humile consisted of two enormous unicolonial supercolonies. Workers of the same supercolony are never aggressive to each other. In contrast, aggressiveness is invariably high between workers from different supercolonies. Here we investigated whether gene flow occurs between two supercolonies. We identified a contact zone in which we sampled 46 nests. For each nest, aggression tests were conducted against workers from reference nests from both supercolonies. Workers were always very aggressive towards workers of one of the supercolonies but not to workers of the other. Thus, all nests could be clearly assigned to one of the two supercolonies. For 22 of the 46 nests, we genotyped 15-16 workers at five microsatellite loci. A four-level hierarchical analysis of variance revealed very strong genetic differentiation between the two supercolonies $\left(F_{\text {SUPERCOLONY-TOTAL }}=0.541\right)$ and low differentiation between sectors (i.e. group of nests connected together with trails) within supercolonies $\left(F_{\text {SECTOR-SUPERCOLONY }}=0.064\right)$. The very high differentiation between the two supercolonies indicates a lack of ongoing gene flow, a conclusion further bolstered by the finding that the two supercolonies share no common alleles at two of the five microsatellite loci. A Bayesian clustering method also revealed the occurrence of two distinct clusters. These clusters exactly match the grouping obtained by aggression tests. None of the 332 genotyped individuals were admixed despite the fact that some nests of the two supercolonies were separated by less than $30 \mathrm{~m}$. These results demonstrate that the two supercolonies have completely separate gene pools.
\end{abstract}

Keywords: aggression tests, contact zone, gene flow, Linepithema humile, supercolony, unicoloniality

Received 20 September 2004; revision received 10 November 2004; accepted 10 November 2004

\section{Introduction}

The Argentine ant, Linepithema humile is a major pest that has been introduced from South America into all other continents that has a Mediterranean climate (Passera 1994; Bolger et al. 2000; Sanders et al. 2003). In its introduced range the Argentine ant displaces or disrupts the local arthropod fauna (Passera 1994; Human \& Gordon 1996), protects insects that devastate cultivated plants (Visser et al. 1996), and invades human houses (Gordon et al. 2001). The ecological domination of introduced populations is thought to stem from their unusual social structure, called

Correspondence: Julie Jaquiéry, Fax: + 41-21-692 4165;

E-mail: Julie.Jaquiery@unil.ch unicoloniality, whereby individuals mix freely among physically separated nests. By reducing costs associated with territoriality, unicoloniality allows high worker densities and contributes to interspecific dominance in invaded habitats (Holway et al. 1998; Holway 1999).

It has been suggested that unicoloniality in L. humile arose from a genetic bottleneck when invasive populations were inadvertently introduced from South America at the end of the 19th century (Passera 1994; Suarez et al. 2001). If kin recognition is based on similarity of heritable cues (Fletcher \& Michener 1987; Hepper 1991; Ratnieks 1991; Vander Meer et al. 1998), a bottleneck may lead to reduced genetic diversity at the recognition locus (loci) and to a loss of aggression between colonies having the same recognition allele(s) (Tsutsui et al. 2000). However, a 
detailed study in Europe revealed that the introduced populations experienced only limited loss of genetic diversity at neutral markers, indicating that the breakdown of recognition ability is unlikely to be merely the result of a genetic bottleneck (Giraud et al. 2002; J.S. Pedersen, T. Giraud, M.J.B. Krieger and L. Keller, unpublished). It has therefore been suggested that the loss of aggression resulted from the specific loss of genetic diversity at recognition loci (Giraud et al. 2002), but this hypothesis remains to be tested.

The study of Argentine ants in Europe also revealed the existence of two supercolonies (Giraud et al. 2002). The main supercolony ranges over $6000 \mathrm{~km}$ of the Atlantic and Mediterranean Coasts, from Italy to Spain. The other supercolony, named the Catalonian supercolony, is apparently much smaller and restricted to the northeastern part of Spain. Workers of the same supercolony are never aggressive to each other despite the large geographical distance $(200-6000 \mathrm{~km})$ and the significant genetic differentiation between sampling sites (main supercolony: $F_{\mathrm{ST}}=0.12$, Catalonian supercolony: $F_{\mathrm{ST}}=0.10$ ) (Giraud et al. 2002). By contrast, aggression is invariably extremely high between the two supercolonies, generally leading to the death of one of the two protagonists during the aggression tests (Giraud et al. 2002).

The existence of strong aggression between workers of the two supercolonies might act as an effective brake on gene flow, which in turn, may have important implications on the evolutionary trajectories of each supercolony. In the study of Giraud et al. (2002), the distance between the sites sampled was too high $(\mathrm{ca} .200 \mathrm{~km})$ to allow a meaningful study of gene flow between the two supercolonies. Gene flow could occur in two ways: (i) either on foot via exchange of workers and/or queens and/or brood between nests, or (ii) on the wing via males entering foreign nests to mate with the virgin queens, as males are frequently seen flying (Newell \& Barber 1913; Markin 1970).

The main goal of this study was to determine the extent of gene flow between the two supercolonies at a microscale. To do this, we first located a contact zone where both supercolonies were sufficiently close to allow exchanges of reproductive individuals between supercolonies. We then performed aggression tests to identify to which supercolony the sampled nests belong. Finally, we used five microsatellite loci to study the extent of gene flow between the two supercolonies.

\section{Materials and methods}

\section{Sampling}

To identify a contact zone between the two supercolonies, we were greatly helped by X. Espadaler \& Gómez (2003). On the basis of the information available, we localized a putative zone of contact between the villages of Pals and Palafrugel, near Girona, northeast Spain on July 2003 $\left(42^{\circ} 57^{\prime} \mathrm{N}, 03^{\circ} 09^{\prime} \mathrm{E}\right)$. All nests found in Pals and along the $6.2 \mathrm{~km}$ road that connects Pals to Palafrugel were sampled, except in places where nests were clearly connected. Nests connected to each other were sampled only every 50-250 meters and were considered as belonging to the same sector (i.e. group of nests connected together with trails). We collected and stored in 95\% alcohol a total of 15-16 workers from each of the 46 nests. The workers used for the behavioural assay were collected on the foraging trail near the nests to ensure that they were not immature.

\section{Aggression tests}

In order to see whether the sampled nests belonged to the Catalonian or main supercolony (Giraud et al. 2002), aggression tests were conducted between pairs of workers. We tested each sampled nest against reference Catalonian and main supercolony workers. Reference main supercolony workers were collected in Castell d'Aro and Catalonian workers in St-Cugat (Giraud et al. 2002). These places are located 18 and $103 \mathrm{~km}$ from the study area, respectively.

For 27 out of 46 nests, we conducted a detailed analysis of the level of aggression using the aggression protocol of Giraud et al. (2002). Aggression tests between pairs of workers were conducted blindly. We randomly selected a single worker from each of two nests and placed them together for 10 minutes in a $5.5 \mathrm{~cm}$ diameter vial with fluon-coated sides. Interactions were scored as follows: $0=$ ignore, physical contact in which neither ant showed any interest; $1=$ antennation, repeated tapping the antennae on the other ant; 2 = avoidance, one or both ants retreating in opposite directions after contact; $3=$ dorsal flexion, gaster raised to vertical position as escalation to chemical defence; 4 = aggression, biting or pulling extremities or head, or deposition of venom; 5 fight, prolonged aggression often involving locking the mandibles onto a body part of the other and/or carrying it. For each trial we recorded the maximum level of aggression. Levels $0-2$ are referred to as nonaggressive and levels $3-5$ are referred to as aggressive behaviour. Six replicate trials were made for each combination of nests. Different workers were used for each trial.

In the 19 remaining nests, we used a simplified version of this test and only determined whether nests belonged to the main or Catalonian surpercolony by conducting three to five replicate trials against each of the two reference supercolonies. These nests were not used in the analyses of aggression.

In order to determine the level of aggressiveness between neighbouring nests that belonged to different supercolonies, we also conducted aggression tests. Three 


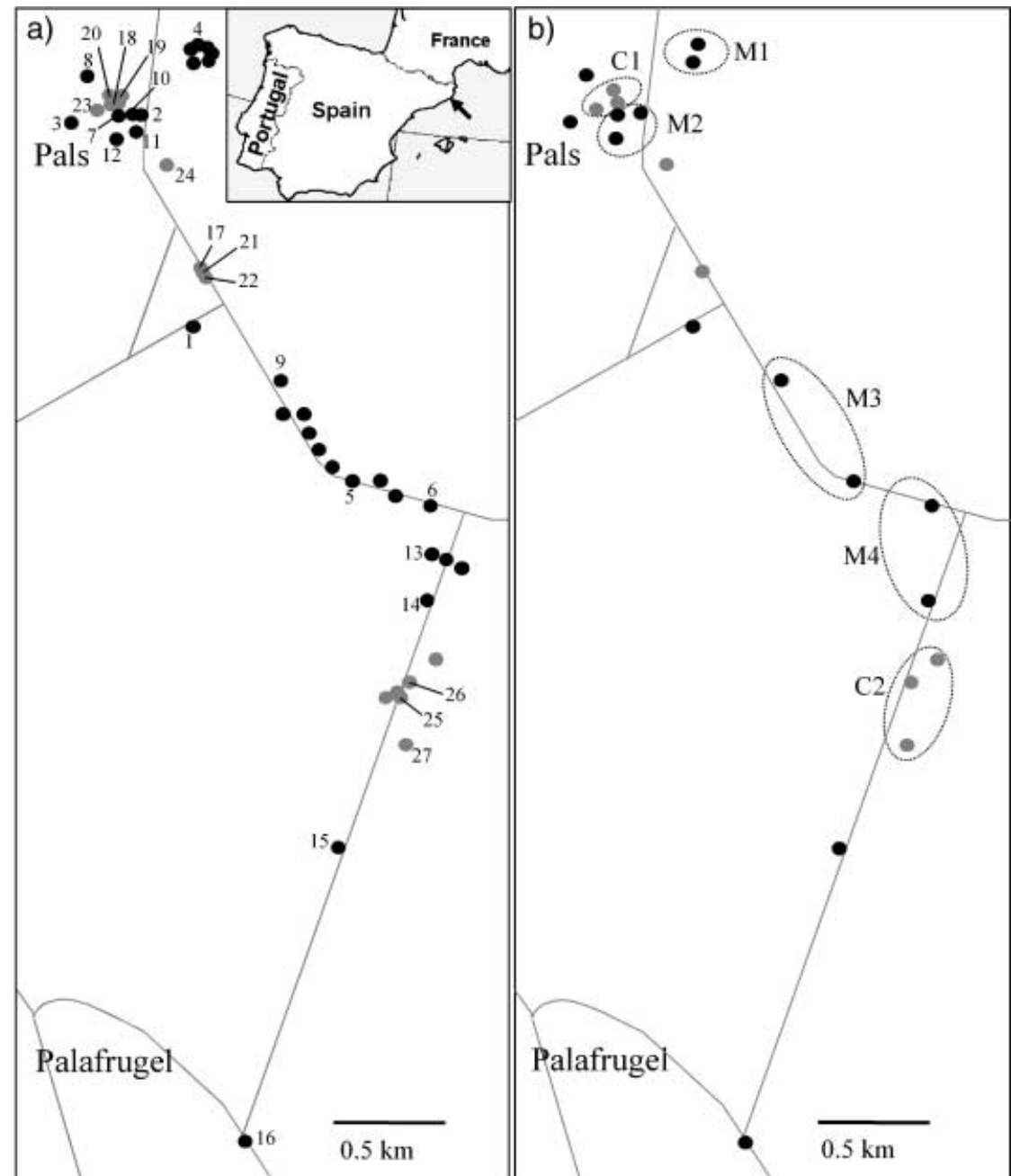

Fig. 1 (a) Map of the sampling sites located near Girone, northeast Spain. The dots with a number indicate nests that were tested following the protocol of Giraud et al. (2002). (b) Map of the nests used for the genetic analyses. Each ellipse defines a sector, either in the main (M1, M2, M3, M4) or in the Catalonian supercolony $(\mathrm{C} 1, \mathrm{C} 2)$. Black circles: nest from main supercolony. Grey circles: nest from Catalonian supercolony.

potential contact zones were identified between nests 7-18, 1-22 and 14-26 (see Fig. 1). For each of the three pairs of nests tested, 18 aggression tests were conducted. The protocol used was the same as in Giraud et al. (2002).

\section{Microsatellite analysis}

Twenty-two out of the 46 sampled nests were used for genetic analyses. The locations of these nests are shown in Fig. 1. These nests were chosen to ensure that all the isolated populations were sampled, and also to allow a hierarchical analysis of genetic variation. DNA was extracted from 15 to 16 workers $(20 \times 15$ and $2 \times 16)$ of each of the 22 nests by using the PUREGENE DNA Isolation Kit (Gentra Systems) and analysed at five microsatellite loci: Lhum-11, Lhum-13, Lhum-18, Lhum-28 and Lhum-35 (Krieger \& Keller 1999). Two loci, Lhum-18 and Lhum-28, were chosen because they were highly discriminating between main and Catalonian supercolonies in a previous study (T. Giraud et al. unpublished). The three others were selected because of their high genetic variability in Linepithema humile European populations (Giraud et al. 2002). PCR (polymerase chain reaction) amplifications were carried out separately for each locus in $16 \mu \mathrm{L}$ final volumes containing approximately $10 \mathrm{ng}$ DNA, $2 \mathrm{~mm} \mathrm{MgCl}_{2}, 1.6 \mu \mathrm{L}$ of $10 \mathrm{x}$ reaction buffer (QIAGEN), $50 \mu \mathrm{M}$ of each dNTP, 0.4 units of Taq polymerase (QIAGEN) and $0.2-0.4 \mu \mathrm{M}$ of fluorescently labelled primers depending on loci. Amplification for all loci involved an initial step of $3 \mathrm{~min}$ at $94{ }^{\circ} \mathrm{C}$, then $34-45$ cycles (depending on the loci) at $92{ }^{\circ} \mathrm{C}$ for $30 \mathrm{~s}, 53{ }^{\circ} \mathrm{C}$ for $30 \mathrm{~s}$ and $72{ }^{\circ} \mathrm{C}$ for $45 \mathrm{~s}$, followed by a final extension of $10 \mathrm{~min}$ at $72{ }^{\circ} \mathrm{C}$. PCR products were run on $5 \%$ Sequagel acrylamide gels on an ABI 377 XL automated sequencer (Applied Biosystems). The gels were subsequently analysed using GENESCAN 3.1.2 (Applied Biosystems).

\section{Hardy-Weinberg and linkage equilibria}

Deviations from Hardy-Weinberg genotype proportions were tested for each supercolony by randomization of alleles among individuals within nests. The F-statistic $F_{\text {IS }}$ was then used to classify contingency table of alleles against 
Table 1 Allelic variation in Linepithema humile, for the main and the Catalonian supercolonies. The number of individuals that were scored, $n$, the expected heterozygosity, $H_{\mathrm{E}}$, and the $P$ value for Hardy-Weinberg tests are given for each locus

\begin{tabular}{|c|c|c|c|c|c|c|c|c|c|c|}
\hline \multirow[b]{2}{*}{ Locus } & \multirow[b]{2}{*}{$\begin{array}{l}\text { No. of allele } \\
\text { (total) }\end{array}$} & \multirow[b]{2}{*}{$\begin{array}{l}\text { Size } \\
\text { range }\end{array}$} & \multicolumn{4}{|c|}{ Main } & \multicolumn{4}{|c|}{ Catalonian } \\
\hline & & & $n$ & $\begin{array}{l}\text { No. of } \\
\text { allele }\end{array}$ & $H_{\mathrm{E}}$ & $\begin{array}{l}\text { HW } \\
\text { test }(p)\end{array}$ & $n$ & $\begin{array}{l}\text { No. of } \\
\text { allele }\end{array}$ & $H_{\mathrm{E}}$ & $\begin{array}{l}\text { HW } \\
\text { test }(p)\end{array}$ \\
\hline Lhum-11 & 8 & $122-136$ & 120 & 6 & 0.547 & 0.91 & 212 & 4 & 0.622 & 0.63 \\
\hline Lhum-13 & 8 & $167-185$ & 119 & 8 & 0.701 & 0.93 & 208 & 3 & 0.175 & 0.99 \\
\hline Lhum-18 & 3 & $111-119$ & 117 & 1 & 0.000 & - & 210 & 2 & 0.157 & 0.99 \\
\hline Lhum-28 & 12 & $179-237$ & 119 & 4 & 0.426 & 0.35 & 210 & 8 & 0.634 & 0.80 \\
\hline Lhum-35 & 25 & $128-232$ & 119 & 13 & 0.493 & 0.006 & 212 & 13 & 0.760 & 0.22 \\
\hline All & & & & & 0.433 & 0.45 & & & 0.470 & 0.81 \\
\hline
\end{tabular}

alleles in each sample. Linkage disequilibrium between pairs of loci in each sample was tested separately for the main and Catalonian supercolonies with G-statistics (Goudet et al. 1996). These analyses were carried out with FSTAT 2.9.4 (Goudet 2001; http://www.2.unil.ch/popgen/softwares/ fstat.html). No significant $(P>0.05)$ departure from HardyWeinberg (HW) proportion was found within nests in the main supercolony, except for one locus, Lhum-35 ( $P=$ 0.006) (Table 1). This suggests that this locus potentially harbours null alleles. In consequence, all analyses were carried out with and without the locus Lhum-35. As all results remained unchanged, we only present the analyses with Lhum-35 included. HW tests within nests, for the Catalonian supercolony showed no significant departure from HW proportions $(P>0.05)$ at any locus. There was no significant ( $G$-statistics, $P>0.05$ ) linkage disequilibrium between pairs of loci in either the Catalonian or the main supercolony.

\section{Hierarchical analyses of variance}

We first conducted a four-level hierarchical $F$-analysis over the whole data set (Weir \& Cockerham 1984; Weir 1996). The levels were individual, nest, sector and supercolony. The supercolony level contained two groups, the main and the Catalonian supercolonies, as identified by the aggression tests. A sector was defined as a group of nests that were connected together with trails. Nests from the main supercolony were grouped in four sectors (M1, M2, M3 and M4) and nests from the Catalonian supercolony in two sectors (C1 and C2) (Fig. 1). Each sector contained two or three nests. We estimated the deficit of heterozygotes within nests $\left(F_{\text {IND-NEST }}\right)$ and the coefficient of genetic differentiation across the different levels ( $F_{\text {NEST-SECTOR' }}$ $\left.F_{\text {SECTOR-SUPERCOLONY }}, F_{\text {SUPERCOLONY-TOTAL }}\right) . F_{\text {NEST-SECTOR }}$ and $F_{\text {SECTOR-SUPERCOLONY }}$ estimated, respectively, the genetic differentiation between nests within sectors and between sectors within supercolonies. $F_{\text {SUPERCOLONY-TOTAL }}$ measured the genetic differentiation between supercolonies. This four-level hierarchical analysis was performed with GENETIC DATA ANALYSIS 1.0 (Lewis \& Zaykin 1999; http:// hydrodictyon.eeb.uconn.edu/people/plewis/software.html). Confidence intervals were obtained by bootstrapping 1000 times over loci. Because bootstrapping across five loci may produce spurious significant results if all estimates are by chance either below or above zero (Raymond \& Rousset 1995), we also tested the significance of the different fixation indices using randomization tests as implemented in FSTAT and ARLEQUIN 2.000 (Schneider et al. 2000; http:// lgb.unige. ch/arlequin). The significance of $F_{\text {IND-NEST }}$ was tested with FSTAT by permuting 5000 times alleles within nests. The significance of $F_{\text {NEST-SECTOR }}$ was tested by 100000 permutations of individuals among nests within sectors with ARLEQUIN. In order to test the significance of $F_{\text {SECTOR-SUPERCOLONY }}$ and to accommodate the hierarchical structure of the data, we analysed each supercolony separately with ARLEQUIN, using a three-level hierarchical analysis. In each supercolony, the significance of $F_{\text {SECTOR-SUPERCOLONY }}$ was tested by 100000 permutations of nests among sectors within supercolonies. We used Fisher's method for combining probabilities of each test per supercolony and thus we obtained a global test of differentiation among sectors within supercolonies. The significance of $F_{\text {SUPERCOLONY-TOTAL }}$ was tested by 100000 permutations between sectors among supercolonies, but using the following approximation for $F_{\text {SUPERCOLONY-TOTAL }}$ :

$$
\begin{aligned}
& \sigma_{\text {among supercolonies }}^{2} /\left(\sigma_{\text {among supercolonies }}^{2}\right. \\
& +\sigma_{\text {among sectors within supercolonies }}^{2} \\
& \left.+\sigma_{\text {among ind. within sectors }}^{2}+\sigma_{\text {within ind. }}^{2}\right)
\end{aligned}
$$

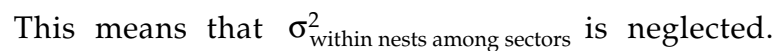
However, this value is very small (-0.004) while $\sigma_{\text {among supercolonies }}^{2}$ is high (2.581) implying that the effect of this approximation on the $P$ value is negligible.

Second, we performed a three-level $F$-hierarchical analysis separately on the main and Catalonian data sets using 
ARLEQUiN (Weir \& Cockerham 1984; Excoffier et al. 1992; Weir 1996) to determine how genetic structure is distributed across levels (individual, nest and sector) within each supercolony. Significance for fixation indices was tested by comparing observed values to a null distribution generated by 100000 permutation, as implemented in ARLEQUIN.

\section{Isolation by distance}

Isolation by distance was tested only for the nests identified as belonging to the main supercolony with aggression tests. We did not test isolation by distance in the Catalonian supercolony because the hierarchical ANOva showed that nests were aggregated in two sectors that were genetically differentiated (see Fig. 1) thus possibly leading to a spurious analysis of isolation by distance. Matrix of pairwise $F_{\mathrm{ST}}$ between nests (calculated with FSTAT) was transformed by $F_{\mathrm{ST}} /\left(1-F_{\mathrm{ST}}\right)$ and the matrix of geographical distance log-transformed as proposed by Rousset (1997) for two-dimensional habitats. The correlation between the two matrices was then tested with a Mantel test following Manly's (1997) algorithm given in FSTAT. To represent visually the genetic differentiation between nests of both supercolonies, we plotted the pairwise $F_{\mathrm{ST}}$ between all nests against the geographical distance.

\section{Assignment tests}

To determine to what extent the clustering of nests obtained with aggression tests was associated with a genetic differentiation between nests, we used the Bayesian clustering method implemented in STRUCTURE 2.1 (Pritchard et al. 2000; http://pritch.bsd.uchicago.edu/). This software infers the number of different clusters $(K)$ that best suit a data set and assigns individuals to the inferred clusters. As individuals can be assigned simultaneously to different clusters, this allows the detection of admixture between clusters. The optimal number of clusters is given by the highest log (likelihood) of the data $[\operatorname{Ln} P(D)]$ or the highest break in slope.

In this analysis, we assumed that all individuals belonged to a hypothetical single population. In other words, no prior knowledge on the origin of the individual (main or Catalonian) was used. We tested all values of $K$ from 1 to 25 . For each $K$, runs were conducted with 20000 iterations, following a burn-in period of 10000 iterations. The most probable $K$ was then estimated by comparing the average of $\operatorname{Ln} P(D)$ over 10 runs for each value of $K$. In addition, for each individual, we inspected its probabilities of belonging to the different inferred clusters with the aim to find admixed individuals. We then compared these clusters with those obtained with aggression tests.

\section{Results}

\section{Aggression tests}

In 310 of 324 (95.7\%) of the 10-minute aggression tests, workers either fought vigorously or showed no sign of antagonism. In the vast majority of cases, all workers of a given nest were aggressive against workers of one supercolony and nonaggressive against workers of the other (Fig. 2). Consequently, nests could be clearly assigned either to the main supercolony or Catalonian supercolony. The location of these nests is given in Fig. 1. The closest distance found between nests from the main and Catalonian supercolonies was only 27 meters.

Aggression tests conducted between workers from the three pairs of neighbouring nests that belonged to different supercolonies also revealed very high levels of aggression. a)

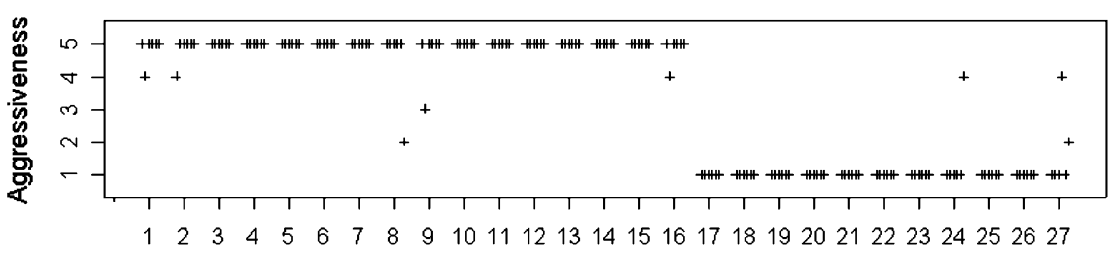

Nest

b)

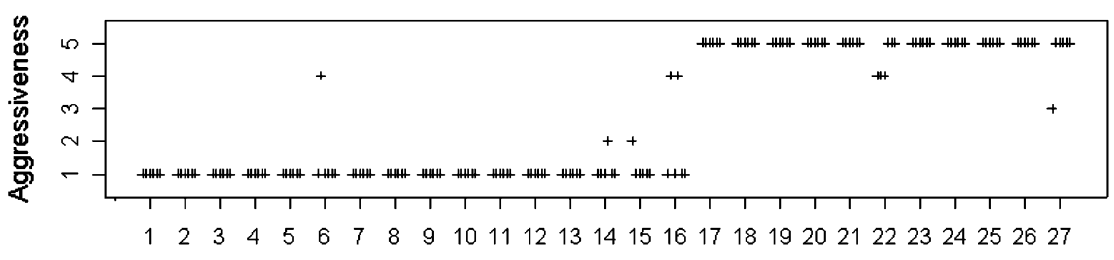

Nest
Fig. 2 Aggression tests between pairs of workers: Each cross represents the maximum level of aggressiveness reached during aggression tests between pairs of workers. All nests were tested against (a) Catalonian reference workers (b) main reference workers. 
The average level of aggression was, respectively, 4.9, 4.5 and 5.0 for the pairs of nests 7-18, 1-22 and 14-26.

\section{Genetic data and hierarchical analyses of variance}

The genetic analyses revealed that two loci, Lhum-18 and Lhum-28, are diagnostic between the two supercolonies: they possess only private alleles for each supercolony (Table 1) and allow a clear distinction between both supercolonies. Moreover, the locus Lhum-18 is monomorphic in the main supercolony.

The four-level hierarchical ANvovA revealed very strong genetic differentiation between the two supercolonies ( $\left.F_{\text {SUPERCOLONY-TOTAL }}=0.541, P<0.0001\right)$ (Table 2$)$. The differentiation between sectors within supercolonies was also significant $\left(F_{\text {SECTOR-SUPERCOLONY }}=0.064, P<0.0001\right)$ whereas the differentiation between nests within sectors $\left(F_{\text {NEST-SECTOR }}=-0.002, P=0.67\right)$ was not statistically significant. There was also no deficit of heterozygotes at the level of the nest $\left(F_{\text {IND-NEST }}=-0.037, P=0.93\right)$. Thus, this analysis shows a very unequal distribution of genetic differentiation across levels with very strong differentiation between supercolonies while the differentiation across lower levels was weak or absent. The level of significance of $F$-statistics was similar whether using randomization or bootstrap across loci.

The three-level hierarchical ANvovAs performed separately on the main and Catalonian data sets gave similar results within each of the two supercolonies (Table 3). The differentiation between sectors was significant (main: $F_{\text {SECTOR-SUPERCOLONY }}=0.083, P<0.0001$, Catalonian: $F_{\text {SECTOR- }}$ SUPERCOLONY $=0.027, P=0.0004$ ) but neither the differentiation between nests within sectors (main: $F_{\text {NEST-SECTOR }}=$ $-0.003, P=0.67$, Catalonian: $\left.F_{\text {nest-sector }}=-0.001, P=0.51\right)$ nor the deficit of heterozygotes within nests (main: $F_{\text {IND-NEST }}=$ $-0.030, P=0.84$, Catalonian: $F_{\text {IND-NEST }}=-0.046, P=0.91$ ) were statistically different from zero.

\section{Isolation by distance}

The pairwise $F_{\mathrm{ST}}$ between nests belonging to different supercolonies was much higher than the pairwise $F_{\mathrm{ST}}$ between nests from the same supercolony (Fig. 3). The $F_{\mathrm{ST}}$ values between nests of the two supercolonies were always high even when geographical distances between nests are very small. Finally, in the main supercolony there was no significant isolation by distance (Mantel test: correlation $r=-0.06, P=0.57,20000$ permutations).

\begin{tabular}{lrrll}
\hline & $F_{\text {IND-NEST }}$ & $F_{\text {NEST-SECTOR }}$ & $F_{\text {SECTOR-SUPERCOLONY }}$ & $F_{\text {SUPERCOLONY-TOTAL }}$ \\
\hline Lhum-11 & -0.090 & 0.005 & 0.112 & 0.364 \\
Lhum-13 & -0.112 & -0.007 & 0.101 & 0.466 \\
Lhum-18 & -0.317 & 0.212 & 0.005 & 0.951 \\
Lhum-28 & -0.038 & -0.009 & 0.022 & 0.523 \\
Lhum-35 & 0.082 & -0.016 & 0.025 & 0.377 \\
All & $\mathbf{- 0 . 0 3 7}$ & $\mathbf{- 0 . 0 0 2}$ & $\mathbf{0 . 0 6 4}$ & $\mathbf{0 . 5 4 1}$ \\
Randomization & & & & \\
P value & 0.929 & 0.674 & $<0.0001$ & 0.0001 \\
Bootstrap & & & & 0.390 \\
Lower 95\% CI & -0.115 & -0.012 & 0.022 & 0.756 \\
Upper 95\% CI & 0.042 & 0.023 & 0.105 & \\
\hline
\end{tabular}

Table 2 Deficit of heterozygotes and population differentiation estimated in a four-level ANOVA for the whole data set

Table 3 Deficit of heterozygotes and population differentiation in a three-level ANova performed separately for the main supercolony and Catalonian supercolony

\begin{tabular}{|c|c|c|c|c|c|c|}
\hline & \multicolumn{3}{|l|}{ Main } & \multicolumn{3}{|c|}{ Catalonian } \\
\hline & $F_{\text {IND-NEST }}$ & $F_{\text {NEST-SECTOR }}$ & $\begin{array}{l}F_{\text {SECTOR- }} \\
\text { SUPERCOLONY }\end{array}$ & $F_{\text {IND-NEST }}$ & $F_{\text {NEST-SECTOR }}$ & $\begin{array}{l}F_{\text {SECTOR- }} \\
\text { SUPERCOLONY }\end{array}$ \\
\hline Lhum-11 & -0.089 & 0.021 & 0.167 & -0.092 & -0.010 & 0.011 \\
\hline Lhum-13 & -0.116 & -0.005 & 0.101 & -0.089 & -0.008 & 0.006 \\
\hline Lhum-18 & - & - & - & -0.317 & 0.193 & 0.058 \\
\hline Lhum-28 & -0.009 & -0.001 & 0.011 & -0.062 & -0.016 & 0.037 \\
\hline Lhum-35 & 0.114 & -0.023 & 0.024 & 0.049 & -0.009 & 0.031 \\
\hline All & -0.030 & -0.003 & 0.083 & -0.046 & -0.001 & 0.027 \\
\hline \multicolumn{7}{|c|}{ Randomization } \\
\hline$P$ value & 0.840 & 0.665 & $<0.0001$ & 0.906 & 0.508 & 0.0004 \\
\hline
\end{tabular}




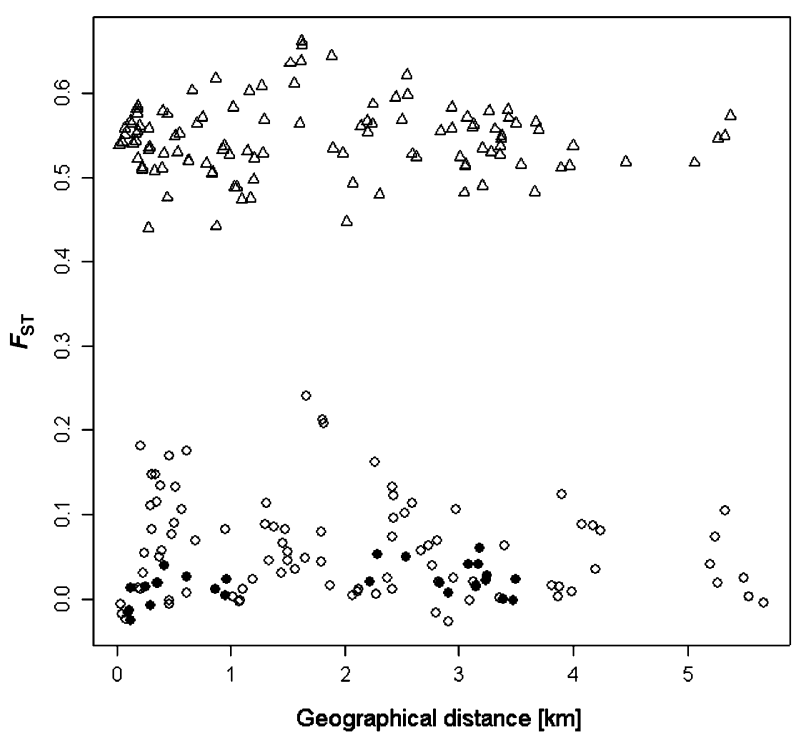

Fig. 3 Pairwise $F_{\mathrm{ST}}$ between all nests plotted against geographical distance. Open circles: comparisons between nests within the main supercolony, filled circles: comparisons between nests within the Catalonian supercolony, triangles: comparisons between nests from different supercolonies.

\section{Assignment tests}

The logarithm of probability of the data $[\operatorname{Ln} P(D)]$ for each value of $K$ (number of inferred clusters in the data set) is shown in Fig. 4. A clear break in slope occured at $K=2$, demonstrating that the number of clusters that best suits the data was $K=2$. Moreover, for $K=2$, all individuals were assigned with a probability $P>0.96$ to one of the two clusters (average $=0.996$ ).

All individuals genotyped from a given nest were always assigned to the same cluster. Thus, eight of the nests were assigned to cluster 1 , and 14 to cluster 2 . These two clusters inferred with STRUCTURE corresponded exactly to the main and Catalonian supercolonies identified by aggression tests.

\section{Discussion}

The first important finding of this study was that all the colonies collected within the contact zone between the main and Catalonian supercolonies could be unambiguously assigned to one of the two supercolonies. All colonies showed the same pattern, with very high level of aggression toward colonies of one of the two supercolonies, but no aggression toward the other. Importantly, the aggressiveness between workers from two different supercolonies in the contact zone was similarly high as in the study of Giraud et al. (2002) where the average distance between nests was more than 100-fold greater. This demonstrates that the level of aggression between individuals of the two

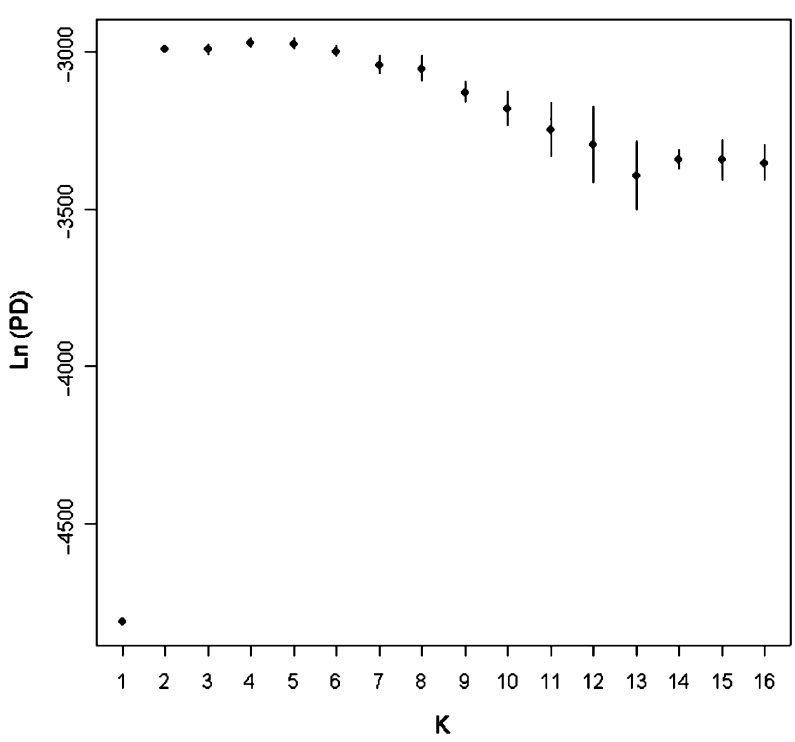

Fig. 4 Average of the logarithm of the likelihood of the data ( $\mathrm{Ln}$ $\mathrm{P}(D)$ ) for 10 independent runs of STRUCTURE (Pritchard et al. 2000) for each value of $K$ between 1 and 16. Only the results for $K$ from 1 to 16 are shown as the average of $\operatorname{Ln} P(D)$ still decreases for $K$ from 16 to 25 . Error bars represent standard deviation over runs.

supercolonies is independent of the distance between nests and also proves that both supercolonies are extremely well defined entities even in a contact zone.

The second important finding of this study was that there is a complete lack of ongoing gene flow between the two supercolonies. The pairwise $F_{\mathrm{ST}}$ between nests from different supercolonies were always very high, whatever their distance. Accordingly, the four-level hierarchical analysis showed that the overall genetic differentiation between the two supercolonies was extremely high $\left(F_{\text {SUPERCOLONY-TOTAL }}=0.54\right)$. This value is somewhat overestimated because two (Lhum-18 and Lhum-28) out of five loci were chosen because they showed high discrimination power between the main and Catalonian supercolony (data from the study of Giraud et al. 2002). However, the genetic differentiation between supercolonies remained very high even when these two loci were not considered ( $F_{\text {SUPERCOLONY-TOTAL }}=0.40$, range $0.36-0.46$ across the three loci).

The complete absence of gene flow between the two supercolonies was demonstrated by the fact that they each had only private alleles at the loci Lhum-18 and Lhum-28, two loci that were found to be diagnostic between the main and Catalonian supercolony in a previous study conducted at a scale of several thousand $\mathrm{km}$ (T. Giraud et al. unpublished). In the contact zone, the main supercolony was fixed for one allele at Lhum-18. By contrast, this allele was absent in the Catalonian supercolony which possessed two alternate alleles. Similarly, the main supercolony had four private alleles at the locus Lhum-28 while the Catalonian 
supercolony possessed eight alleles that were completely absent in the main supercolony.

The analysis performed with the program STRUCTURE also revealed a lack of gene flow between the two supercolonies. On the basis of their genotype, all individuals were assigned with a very high probability to one of two clusters. All individuals of the same colony were assigned to the same cluster. Importantly, these clusters matched exactly to the main and Catalonian supercolonies as identified by aggression tests, confirming that the unity of supercolony is meaningful from both a behavioural and genetic perspective. As the probability of belonging to one of the two clusters was close to one for all individuals, this demonstrates that none of the 332 genotyped individuals were admixed. A calculation of power using a binomial distribution shows that the sample size of this study $(N=332)$ was sufficiently high to permit detection of even a small level of admixture. Thus, the probability of detecting at least one admixed individual would be greater than 0.95 if the frequency of admixing was equal or greater than $0.9 \%$.

The findings of this study have important implications for our understanding of the origin of European populations of Argentine ants. The very strong genetic differentiation and the complete lack of gene flow between the main and Catalonian supercolonies are consistent with the hypothesis of two introduction events. Unfortunately, the genetic data on the native populations in Argentina are scarce and do not allow us to make clear comparisons with the genetic structure of the two European supercolonies. Tsutsui \& Case (2001) studied three locations containing two or more groups of nests which were aggressive to each other. In two of the locations, the pairwise $F_{\mathrm{ST}}$ between nests belonging to the same group of nonaggressive nests was weak (from -0.03 to 0.07 ) while the pairwise $F_{\mathrm{ST}}$ between nests belonging to groups of nests aggressive to each other was higher (from 0.18 to 0.36 ). Unfortunately, no information was given on the third location and the available data do not allow us to evaluate whether gene flow occurred between groups of nests that were aggressive to each other. Whatever the exact nature of gene flow between groups of nests in Argentina, the data show that strong genetic differentiation between groups of nests also occur in South America, raising the possibility that independent introductions in Europe may account for the strong genetic differentiation between the main and Catalonian surpercolonies.

The second important consequence is that the two supercolonies effectively behave as independent gene pools. There is no ongoing gene flow and there is a very strong aggression between the two supercolonies. Indeed we found two diagnostic genetic markers allowing us to unambiguously discriminate between the two supercolonies. It remains to be investigated whether the complete genetic isolation between the two supercolonies evolved after the introduction to Europe or whether such a pattern already occurred in the native habitat.

The three- and four-level hierarchical analyses revealed weak but significant structure between sectors within each of the two supercolonies but neither the differentiation between nests within sectors $\left(F_{\text {NEST-SECTOR }}\right)$ nor deficit of heterozygotes at the nest level ( $\left.F_{\text {IND-NEST }}\right)$ was statistically different from zero. These results suggest that patterns of dispersal and mating are similar in the two supercolonies. The nonsignificant $F_{\text {IND-NEST }}$ and $F_{\text {NEST-SECTOR }}$ found in both supercolonies are in accordance with the results of previous studies conducted in introduced populations in France (Krieger \& Keller 2000), Hawaii (Ingram 2002) and California (Ingram \& Gordon 2003). The lack of differentiation between nests within sectors could be explained either by recent spatial expansion of colonies within each sector or by movements of workers or queens across nests in the same sector.

The genetic analyses also revealed a lack of isolation by distance between colonies of the main supercolony. Similar results were also found at a scale of $2 \mathrm{~km}$ in another population of the main supercolony in Port Leucate, France (Reuter et al. 2001) as well as in an introduced population in California where the habitat was continuous (Ingram \& Gordon 2003). There are two possible explanations for the absence of isolation by distance. The first is the occurrence of significant dispersal between nests thus homogenizing allele frequencies. However, this explanation is unlikely because our study showed limited dispersal and significant genetic differentiation between sectors. This limited dispersal most likely reflects the biology of Linepithema humile, a species where queens cannot disperse on the wing and where mating takes place within the nest (Markin 1970; Passera \& Keller 1992). Thus, gene flow can occur only by males entering foreign colonies where they mate with resident queens and/or queens and workers dispersing between close nests on foot (Newell \& Barber 1913; Markin 1970). The alternative and more likely explanation for the lack of isolation by distance is the occurrence of jump dispersal (Holway 1995; Suarez et al. 2001). Argentine ant nests can readily be transported in potted plants, coffee shipments or firewood (Barber 1916; Holway 1995) and natural or human-mediated dispersal events can thus occur over large distances (from $10 \mathrm{~km}$ to more than $1000 \mathrm{~km}$ ) (Suarez et al. 2001). The fact that the study area consists of cultivated fields with a few industrial areas provides many opportunities for jump dispersal to occur with transport of items by humans. Such a mode of dispersal would not lead to isolation by distance at the scale of this study because close nest aggregation would not be more likely to originate from the same population than from more distant nest aggregations.

In conclusion, this study reveals that the two supercolonies are extremely well-defined entities even within 
a contact zone. The level of aggression is invariably high between individuals of the two supercolonies. Moreover, there is very strong genetic differentiation between the two supercolonies and a complete lack of ongoing gene flow, even when nests are as close as $27 \mathrm{~m}$. The most likely explanation for these findings is that there have been at least two introduction events in Europe with each supercolony originating from a distinct South American population. Whatever the mechanism responsible for the current pattern, the finding that there is no gene flow between the two supercolonies has important implications because each supercolony should now be considered as an independent gene pool following its own evolutionary trajectory.

\section{Acknowledgements}

We thank Xavier Espadaler for his great help during field work. We would also like to thank Jérôme Goudet, Pierre Fontanillas, Guillaume Evanno, Michel Chapuisat, two reviewers and the Associate Editor for helpful discussions and comments on the manuscript. We thank Christian Bernasconi for his help for some parts of laboratory work, and Karen Parker for improving our English. This work was supported by the Swiss NSF.

\section{References}

Barber ER (1916) The Argentine ant: distribution and control in the United States. USDA Bureau Entomology Bulletin, 377, 1-23.

Bolger DT, Suarez AV, Crooks KR, Morrison SA, Case TJ (2000) Arthropods in urban habitat fragments in Southern California: area, age, and edge effects. Ecological Applications, 10, 1230-1248.

Espadaler X, Gómez C (2003) The Argentine ant, Linepithema humile in the Iberian Peninsula. Sociobiology, 42, 187-197.

Excoffier L, Smouse PE, Quattro JM (1992) Analysis of molecular variance inferred from metric distances among DNA haplotypes: application to human mitochondrial DNA restriction data. Genetics, 131, 479-491.

Fletcher DJC, Michener CD (1987) Kin Recognition in Animals. John Wiley and Sons, Chichester.

Giraud T, Pedersen JS, Keller L (2002) Evolution of supercolonies: the Argentine ants of southern Europe. Proceedings of the National Academy of Sciences of the United States of America, 99, 6075-6079.

Gordon DM, Moses L, Falkovitz-Halpern M, Wong EH (2001) Effect of weather on infestation of buildings by the invasive Argentine ant, Linepithema humile (Hymenoptera: Formicidae). American Midland Naturalist, 146, 321-328.

Goudet J (2001) FSTAT, a Program to Estimate and Test Gene Diversities and Fixation Indices. Ver 294. Department of Ecology and Evolution, University of Lausanne, Lausanne.

Goudet J, Raymond M, deMeeus T, Rousset F (1996) Testing differentiation in diploid populations. Genetics, 144, 1933-1940.

Hepper PG (1991) Kin Recognition. Cambridge University Press, Cambridge.

Holway DA (1995) Distribution of the Argentine ant (Linepithema humile) in northern California. Conservation Biology, 9, 16341637.

Holway DA (1999) Competitive mechanisms underlying the dis- placement of native ants by the invasive Argentine ant. Ecology, 80, 238-251.

Holway DA, Suarez AV, Case TJ (1998) Loss of intraspecific aggression in the success of a widespread invasive social insect. Science, 282, 949-952.

Human KG, Gordon DM (1996) Exploitation and interference competition between the invasive Argentine ant, Linepithema humile, and native ant species. Oecologia, 105, 405-412.

Ingram KK (2002) Plasticity in queen number and social structure in the invasive Argentine ant (Linepithema humile). Evolution, 56, 2008-2016.

Ingram KK, Gordon DM (2003) Genetic analysis of dispersal dynamics in an invading population of Argentine ants. Ecology, 84, 2832-2842.

Krieger MJB, Keller L (1999) Low polymorphism at 19 microsatellite loci in a French population of Argentine ants (Linepithema humile). Molecular Ecology, 8, 1078-1080.

Krieger MJB, Keller L (2000) Mating frequency and genetic structure of the Argentine ant Linepithema humile. Molecular Ecology, 9, 119-126.

Lewis PO, Zaykin D (1999) GENETIC DATA ANALYSIS 1.0 (d16c), A Computer Program for Analysis of Allelic Data. University of Conneticut, Storr.

Manly BGF (1997) Randomization and Monte Carlo Methods in Biology, 2nd edn. Chapman \& Hall, London.

Markin GP (1970) Seasonal life cycle of Argentine ant, Iridomyrmex humilis (Hymenoptera, Formicidae), in Southern California. Annals of the Entomological Society of America, 63, 1238-1242.

Newell W, Barber TC (1913) The Argentine ant. USDA Bureau Entomology Bulletin, 122, 1-98.

Passera L (1994) Characteristics of tramp species. In: Exotic Ants: Biology, Impact, and Control of Introduced Species (ed William DF), pp. 23-43. Westview Press, Boulder, Colorado.

Passera L, Keller L (1992) The period of sexual-maturation and the age at mating in Iridomyrmex-humilis, an ant with intranidal mating. Journal of Zoology, 228, 141-153.

Pritchard JK, Stephens M, Donnelly P (2000) Inference of population structure using multilocus genotype data. Genetics, 155, 945-959.

Ratnieks FLW (1991) Evolution of genetic odor-cue diversity in social Hymenoptera. American Naturalist, 137, 202-226.

Raymond M, Rousset F (1995) An exact test for population differentiation. Evolution, 49, 1280-1283.

Reuter M, Balloux F, Lehmann L, Keller L (2001) Kin structure and queen execution in the Argentine ant Linepithema humile. Journal of Evolutionary Biology, 14, 954-958.

Rousset F (1997) Genetic differentiation and estimation of gene flow from $F$-statistics under isolation by distance. Genetics, 145, 1219-1228.

Sanders NJ, Gotelli NJ, Heller NE, Gordon DM (2003) Community disassembly by an invasive species. Proceedings of the National Academy of Sciences of the United States of America, 100, 2474-2477.

Schneider S, Roessli D, Excoffier L (2000) ARLEQUIN, Version 2.000: a Software for Population Genetics Data Analysis Genetics and Biometry Laboratory. University of Geneva, Geneva.

Suarez AV, Holway DA, Case TJ (2001) Patterns of spread in biological invasions dominated by long-distance jump dispersal: insights from Argentine ants. Proceedings of the National Academy of Sciences of the United States of America, 98, 1095-1100.

Tsutsui ND, Case TJ (2001) Population genetics and colony structure of the Argentine ant (Linepithema humile) in its native and introduced ranges. Evolution, 55, 976-985. 
Tsutsui ND, Suarez AV, Holway DA, Case TJ (2000) Reduced genetic variation and the success of an invasive species. Proceedings of the National Academy of Sciences of the United States of America, 97, 5948-5953.

Vander Meer RK, Breed MD, Winston ML, Espilie KE (1998) Pheromone Communication in Social Insects: Ants, Wasps, Bees, and Termites. Westview Press, Boulder, Colorado.

Visser D, Wright MG, Giliomee JH (1996) The effect of the Argentine ant, Linepithema humile (Mayr) (Hymenoptera: Formicidae), on flower-visiting insects of Protea nitida Mill (Proteaceae). African Entomology, 4, 285-287.

Weir BS (1996) Genetic Data Analysis II. Sinauer Associates, Sunderland, MA.
Weir BS, Cockerham CC (1984) Estimating F-Statistics for the analysis of population structure. Evolution, 38, 13581370.

This work is part of the Master thesis written by J. Jaquiéry, under the supervision of V. Vogel and L. Keller. V. Vogel (PhD student) is studying different aspects of social organization and population genetic structure of Linepithema humile. L. Keller works on various aspects of evolutionary ecology such as reproductive skew, sex allocation, caste determination, molecular basis of ageing and social behaviour in ants. 